\title{
RECENZJE
}

Klio. Czasopismo poświęcone dziejom Polski i powszechnym PL ISSN 1643-8191, t. 24 (1)/2013, s. 207-218

cc) $\odot$ DOI: $10.12775 / \mathrm{KLIO} .2013 .010$

\section{Dorota Żołądź-Strzelczyk, Katarzyna Kabacińska-łuczak, Codzienność dziecięca opisana słowem i obrazem. Życie dziecka na ziemiach polskich od XVI do XVIII wieku, Wydawnictwo DiG, Warszawa 2012, ss. 192}

$\mathrm{D}$ ziecko, dzieciństwo oraz jego aspekty w okresie przedrozbiorowym są wiodącą tematyką rozważań naukowych autorek recenzowanej pracy. Pierwsza z nich, Dorota Żołądź-Strzelczyk, jest pracownikiem Zakładu Historii Wychowania Wydziału Studiów Edukacyjnych Uniwersytetu im. Adama Mickiewicza w Poznaniu. Problematykę dzieciństwa autorka poruszała w swoich poprzednich publikacjach. Również tematyka historii wychowania i edukacji kobiet jest jej bliska. Druga z autorek, Katarzyna Kabacińska-Łuczak, również pracuje w Zakładzie Wychowania wspomnianego Uniwersytetu. Do najważniejszych publikacji badaczki można zaliczyć m.in. Zabawy i zabawki dziecięce w osiemnastowiecznej Polsce, Ktopoty w wychowaniu matych dzieci w świetle wybranych pamiętników osiemnastowiecz$n y c^{* *}$. Recenzowana książka nie jest pierwszym owocem współpracy obu badaczek, miały już bowiem okazję pracować razem przy książce Dawne

D. Żołądź-Strzelczyk, Dziecko w dawnej Polsce, Poznań 2002; eadem, Dzieciobiorki, peporzezki, baby - kto zajmowat się „babieniem” w dawnej Polsce, [w:] Cognitioni gestorum. Studia z dziejów średniowiecza dedykowane Profesorowi Jerzemu Strzelczykowi, red. D. A. Sikorski, A. M. Wyrwa, Poznań-Warszawa 2006, s. 571-580.

"* K. Kabacińska-Łuczak, Zabawy i zabawki dziecięce w osiemnastowiecznej Polsce, Poznań 2007; eadem, Ktopoty $w$ wychowaniu matych dzieci w świetle wybranych pamiętników osiemnastowiecznych, [w:] Sytuacje trudne w życiu dziecka, red. M. Cywińska, Poznań 2008, s. 121-134. 
i wspótczesne zabawki dziecięce $e^{* * *}$. Recenzowana książka jest rezultatem badań prowadzonych w ramach projektu pt. „Dziecko w ikonografii staropolskiej" (nr 3146/H03/2007/32) dofinansowanego przez Ministerstwo Nauki i Szkolnictwa Wyższego.

Książka wydana nakładem Wydawnictwa DiG w 2012 roku jest bogato ilustrowana i wydana z dbałością o szczegóły. Składa się ze wstępu, sześciu rozdziałów, z których każdy ma po kilka podrozdziałów, zakończenia, bibliografii; dodano także wykaz fotografii, indeks osób i na końcu indeks miejscowości. We wstępie autorki przedstawiają tematykę swojej książki, stan badań, zakres wykorzystanej literatury - dotyczącej zarówno dziejów obyczajów jak i historii sztuki - oraz inne typy źródeł wykorzystanych w pracy. Następnie przedstawiają cel badawczy, opisują krótko poszczególne etapy swojej pracy i na końcu dziękują wszystkim tym, którzy pomagali i przyczynili się do wydania tego dzieła.

Rozdział pierwszy, „Narodziny i początek życia”, ukazuje czytelnikowi pierwsze chwile dziecka na świecie, od porodu, poprzez połóg matki do chrztu. O tym, jak ważna była dla kobiety ciąża i moment porodu, dowiadujemy się z podrozdziału „W niebezpieczeństwie śmiertelny się rodzi”. Kobiecie towarzyszyła położna oraz często inne kobiety, potrzebne były także odpowiednie sprzęty, takie jak: miska i dzbany z ciepłą wodą, pieluchy, ręczniki, kołyska i pościel. Autorki podają tu liczne przykłady ikonograficzne, w większości były to przedstawienia narodzin Marii, które były bardzo popularne w okresie wczesnonowożytnym. Kolejnym etapem po narodzeniu była pierwsza kąpiel, zawsze w ciepłej wodzie z odpowiednimi ziołami i innymi dodatkami, o czym czytamy w podrozdziale „Kąpiałeczka gotowa, przyprawiona zioły". W tym przypadku również oglądamy kolorowe ilustracje - fragmenty obrazów, na których widzimy także, jak trudno malarzom przedstawić niemowlęta, które często były dużo większe i „grubsze” niż w rzeczywistości. „Okrutny zwyczaj krępowania niemowląt powijakami - powijaki pierwszym ubiorem dziecka" to opis sposobu zawijania nowonarodzonych w powijaki i pieluszki, po której to czynności „Zaraz od urodzenia dziecię kładziono do kolebki”. O tym, jak wyglądały koły-

*** Dawne i wspótczesne zabawki dziecięce, red. D. Żołądź-Strzelczyk, K. Kabacińska, Poznań 2010. 
ski, wiemy zarówno ze źródeł pisemnych, jak i ikonograficznych. Były to zarówno kolebki, które można było przenosić, jak i takie, które stanowiły stałe wyposażenie izby czy pokoju. Umyte i ułożone do snu dziecko prędzej czy później bywało głodne, a „Pokarm matczyn najzdrowszy jest dziecięciu", więc najbardziej wskazane było karmienie przez kobietę piersią. Zdarzało się oczywiście „wynajmowanie" mamek, ale dotyczyło to głównie kobiet z wyższych sfer, które było na to stać. Pierwszy etap życia noworodka kończył chrzest. W podrozdziale „Chrzciny sprawiliśmy niedawno urodzonemu" czytamy o tym, jak wyglądała ta uroczystość w rodzinach królewskich. Dziecko miało na sobie specjalne stroje, uroczystość odbywała się oczywiście w kościele i po niej najczęściej następował uroczysty obiad.

Rozdział drugi, „W rodzinie”, dotyczy miejsca dziecka w tej podstawowej komórce społecznej. W podrozdziałach „Owy dziateczki wdzięcznie przypadną - dzietność rodziny” i „Rodzicy i dziatki - relacje w rodzinie” autorki przedstawily średnią liczebność rodziny, śmiertelność dzieci oraz sposób ukazywania tych aspektów w ikonografii. Często bowiem zdarzało się, że nieżyjące już dzieci były ukazywane na obrazach, tyle że nad ich główkami malowano m.in. krzyże. Obrazy ukazywały również hierarchię, relacje w rodzinie, szacunek i miłość, jaką się darzono. Bywały przypad$\mathrm{ki}-\mathrm{i}$ to nierzadkie - gdy rodzice powierzali wychowanie swoich pociech zaufanej osobie, ale większość obrazów ukazuje zażyłe stosunki wśród najbliższych.

Kolejna część książki, rozdział trzeci „Szatki niekosztowne, ale wżdy świetne", wskazuje na to, jak wyglądały stroje dziecięce od najmłodszych lat. Bogaci ubierali swoje dzieci strojnie i kolorowo, biedniejsze dzieci „nosity po sobie” lub dorośli przerabiali swoją odzież na dziecięcą. Bardzo ważne było nakrycie głowy, które oprócz dbania o ciepło chroniły główkę przed urazami powstałymi na skutek upadków i innych urazów. Najmłodsi ubierani byli w białe koszulki, które z czasem za pomocą dodawanych koronek, przepasek i kokardek przybierały wygląd strojów dla dorosłych. Dziewczynki z czasem ubierały fartuszki, letniki, sukienki, spódniczki, kolorowe czepki i inne przepaski na głowę. Zdarzało się - i to nierzadko - że dziewczynki, wypełniając śluby rodziców, nosiły habity jak zakonnice. Chłopcy na początku podobnie jak dziewczynki zakładali koszulki lub sukienki, ale dorastając dostawali już stroje jak dla dorosłych - „Żupanik 
i kontusik". Autorki przytaczają wiele fragmentów pamiętników i obrazów potwierdzających przedstawiane wnioski. W późniejszym okresie dzieci ubierane były albo na wzór polski, albo europejski, co znalazło odzwierciedlenie na portretach z XVIII wieku. Oczywiście „Na królewskim dworze” stroje były dużo bardziej ozdobne, materiały lepszego gatunku, a kroje częściej inspirowane modą zachodnią.

„Domowe sprzęty pomniejsze dla dzieci”, czyli rozdział czwarty, przybliża czytelnikom „Miejsce dla dziecka w domu”, „Łóżka pomniejsze i białe szaty malińskie”, „Krzesełka pomniejsze i stołki do biegania dzieciom”, przedmioty do kąpieli oraz naczynia do karmienia. Rzadko zdarzało się, by dzieci miały osobny pokój - a przynajmniej źródła nie dostarczają wielu informacji na ten temat - w większości przypadków dzieliły go z rodzicami, a nawet wujami, ciotkami czy dziadkami. W inwentarzach pojawiają się informacje o małych łóżeczkach, kołderkach, rzadziej czytamy o stołkach czy krzesełkach dla dzieci. Więcej informacji, zarówno w źródłach pisanych, jak i ikonograficznych, autorki znalazły na temat specjalnych chodzików. Inne przedmioty potrzebne do pielęgnowania dzieci to urynaliki oraz naczynia do kąpieli i mycia. „Naczynia do karmienia” to kolejna grupa sprzętów domowych, spośród których wyróżnić można poidełka, butelki, miseczki i łyżeczki dostosowane kształtem i wielkością do potrzeb najmłodszych.

Z rozdziału piątego, „Zabawa i edukacja”, dowiadujemy się, jak ważna w okresie wczesnonowożytnym była, zarówno dla dzieci, jak i dla dorosłych, zabawa. Zabawkami okazywały się najprostsze przyrządy, patyki, liście, sznurki, a także typowe zabawki, takie jak: grzechotki, bąki, pajacyki, lalki, piłki. Jak i dzisiaj, kiedy kończył się czas beztroskiej zabawy, rozpoczynał się czas obowiązku nauki w szkole. Część dzieci miała swoich nauczycieli na co dzień w domach, inni wyjeżdżali na nauki nawet za granicę. O ile mało jest źródeł na temat pierwszego sposobu nauczania, o tyle wiele jest w książce przykładów ikonografii, na której uwieczniono dzieci w szkole, słuchające wykładu, czy też chłopców idących z książkami do szkoły.

Innowacyjny i unikatowy jest rozdział szósty pt. „Przed obraz przyniesione cudownie zdrowe było - troska o dzieci - obrazy wotywne i opisy cudów". Autorki odnalazły wiele przykładów na to, jak w potrzebie błagano o pomoc świętych. Podają przykłady wierszy, fragmenty pamiętników, opisy cudownych uzdrowień z bezdzietności, uzdrowień niemowląt i starszych dzieci, informacje o pomocy dzieciom po wypadkach, a nawet przypadki 
przywracania życia zmarłym. Po tych wszystkich cudach udawano się do kościołów z podziękowaniem, co też często uwieczniano na obrazach.

W krótkim zakończeniu autorki podsumowują swoją pracę, porównują typy źródeł i podkreślają, że ich książka może posłużyć nie tylko historykom, historykom sztuki, czy też historykom wychowania, ale także każdemu, kogo interesuje tematyka dzieciństwa i codzienności dziecka w poprzednich epokach.

Ważną zaletą książki jest wspomniana już strona graficzna i to, że autorki mogły pozwolić sobie na tak pełne ukazanie źródeł ikonograficznych, stanowiących sporą część omawianej publikacji. Rozdziały i podrozdziały poświęcone różnym aspektom podjętego zagadnienia są prawidłowo wydzielone. Autorki przedstawiły wszystkie główne problemy związane z badaniami nad historią dzieciństwa. Reasumując praca Doroty ŻołądźStrzelczyk i Katarzyny Kabacińskiej-Łuczak jest przykładem bardzo dobrej monografii. Szeroka i zróżnicowana kwerenda przeprowadzona w wielu archiwach w całym kraju była dokładna i wyczerpująca, wszystkie informacje i wnioski oparto na przykładach zaczerpniętych z materiałów źródłowych. Całość napisana jest językiem zrozumiałym, zarówno dla naukowców, jak i innych zainteresowanych tematem, co czyni książkę dostępną dla szerokiego grona odbiorców. 